\title{
Identifying and Ranking Criteria of Good Governance in Project-Based Organizations
}

\author{
Samira Aeini ${ }^{1}$, Mehdi Delavari ${ }^{2}$, and Yaser Goldust ${ }^{3}$ \\ ${ }^{1}$ Master student in Project and Construction Management, Noore Touba University, Tehran, Iran. E-mail: \\ aeini.samira1987@gmail.com \\ ${ }^{2}$ Ph.D. in Project Management and Construction, Tarbiat Modares University, Tehran, Iran. E-mail: \\ delavari_mehdi@yahoo.com (corresponding author). \\ ${ }^{3}$ Assistant professor, Department of Architecture, Faculty of Art and Architecture, University of Mazandaran, Babolsar, \\ Iran. E-mail: y.goldust@umz.ac.ir
}

Project Management

Received April 3, 2021; revised April 13, 2021; October 18, 2021; accepted October 31, 2021

Available online December 30, 2021

\begin{abstract}
Good governance plays a key role in the growth and success of organizations and helps them to achieve their strategic goals. A review of the research literature shows that the term good governance is mostly used in relation to governments, and there is no proper understanding of the role of good governance in non-governmental organizations. Due to the significant growth of project-oriented organizations, there is a gap in the literature to explain the position of good governance in project-based organizations. For this reason, there is no good understanding of the term good governance and its application in project-based organizations. The purpose of this study is to identify and prioritize the criteria of good governance in Iranian project-based organizations. To this end, a hybrid approach based on meta-synthesis, thematic analysis, and multi-criteria decision-making methods was used to identify and prioritize good governance criteria in project-based organizations. In the first phase, using the meta-synthesis method, an extensive review of the good governance literature from 2012 to 2020 was conducted and different criteria of good governance were extracted. In the second phase, the thematic analysis method was used to identify good governance criteria through interviews with 10 experts active in project-based organizations. In the third phase, the best-worst method (BWM) method was used to weigh and prioritize the good governance criteria. The results of data analysis indicated that accountability is the most important criterion, and the planning to respond to risks and uncertainties is the most important sub-criterion of the research. Finally, some managerial implications for managers of project-based organizations and some future research directions were provided.
\end{abstract}

Keywords: Good governance, project-based organizations, meta-synthesis, thematic analysis, best-worst method (BWM)

Copyright $(\mathcal{C}$ Journal of Engineering, Project, and Production Management (EPPM-Journal).

DOI 10.32738/JEPPM-2022-0007

\section{Introduction}

Good governance in projects has become an important topic for discussion in articles. Organizations try to achieve their organizational goals using this approach. The organizations start projects with the best goals and with the hope of success, but due to issues related to governance and management, many projects fail, and its reason is often unknown. Traditionally, evaluation of project results in terms of their completion in the determined scope, time, cost, and quality has been measured. However, evaluation of projects is extended toward governance to enable the companies to achieve their strategic goals in a significant period of time. Therefore, good and effective governance is essential for project-based organizations (Reside et al., 2010). On the other hand, the failure of large projects with huge capital has highlighted the consequences of inefficient governance (Flyvbjerg et al., 2003). In addition, Guo et al. (2014) concluded that in infrastructure projects, complexities and uncertainties are very common. Integrating internal management of projects with governance to achieve their strategic goals has caused many organizational challenges. Levitt et al. (2009) have discussed the ownership and commitment of the project sponsor (here the governance) against the project manager in long-term infrastructure development projects. They have also suggested specific approaches to address governance challenges arising from different stages of the project in public and private organizations. Miller et al. (2001) stated that during the lifecycle of public-private partnership infrastructure development projects, uncertainties and unpredictability are very high. These ambiguities and instabilities can be observed like many other governance issues in the form of political and legal 
issues about projects. On the other hand, the countries are classified into two categories of developed and underdeveloped countries in terms of their economy and based on taxes, infrastructure, and a good governance environment. Developed countries are those countries with a good governance environment, good infrastructure, and a very accurate tax system (Goodspeed et al., 2011). Before the mid-90s of the last century, the concept of "good governance" has particularly used in international organizations such as the World Bank, the United Nations Development Program, and other international organizations. Recently, the principles of good governance have been developed into local, regional, and private organizations, especially in developing countries (Abdou, 2021). Delavari et al. (2021) worked on developing good governance principles for the private sector. They focused on adapting the good governance criteria with the nature of the activities in project-based organizations.

Reviewing the literature of foreign projects shows that good governance is one of the main parameters of previous sources of project-based organizations such as the construction industry. Moreover, the impact of governance on public sector infrastructure projects in the last decade has become an important issue in every project (Khan et al., 2018). Poor performance of governments in completing the projects has led the managers and researchers to find a relationship between good governance and its impact on the project success. Moreover, there are very few studies in the country that address the issue of good governance criteria, particularly in project-based organizations. Therefore, the purpose of the present study is to identify and rank the criteria of good governance. This study tries to answer the following questions:

- What are the criteria and sub-criteria of good governance in Iranian project-based organizations?

- How important is each of these criteria in projectbased organizations?

To answer the above questions, a combined method composed of three meta-synthesis, thematic analysis, and multi-criteria decision-making methods is used to identify and rank the criteria of good governance.

In the following, while presenting theoretical foundations, the studies conducted in the field of good governance have been evaluated. Then, in the research methodology section, the statistical population and sample of this research and the steps of each analysis method have been addressed. In the fourth section, first using the metasynthesis method and theme analysis, the criteria of good governance have been identified and extracted. Then, using the BWM method, the weight and significance of each criterion of the research were obtained. In the final section, the conclusion and practical suggestions, and scientific suggestions for future studies are presented.

\section{Theoretical Foundations and Research Background}

\subsection{Good Governance}

For a long time, the concept of good governance was used for running an organization or a government. For example, Philip Selznik developed the concept of governance in his studies about industrial organizations (Winston, 2012). But later, the concept of good governance gained a stable position in development programs; then it was applied in the field of human rights (Kjoer and Kinnerup, 2002). Governance is a process through which public institutions manage public affairs and public resources and ensure the realization of human rights. Good governance organizes this issue in a way free from abuse and corruption and with desirable attention to the governance of law (Weiss, 2000).

The concept of good governance is defined by the Human Rights Commission working group with five key features. The Human Rights Commission considers five elements of transparency, accountability, responsiveness, participation, and effectiveness based on the needs of people to achieve good governance. With these five elements, an environment is provided in which human right is achieved, and proper human development becomes possible.

Good governance at the national and global level can organize the development process in such a way that finally leads to the elimination of poverty. However, still, there is no definition of good governance that is completely agreed by everyone, and there is a disagreement on its concept and content. Considering all these interpretations, good governance is a term that is still controversial. Although it has been a long time that many concepts are presented in the democratic literature with their elements and definition, there is no comprehensive and precise agreement on this term. Therefore, this study attempts to review the conducted studies in this field and present a hierarchical model of good governance criteria in projectbased organizations.

\subsection{Features and Functions of Good Governance}

Given the extensive definition of the concept of good governance and its scope, a wide range of goals and functions have been considered for it. Creating civil liberties, strengthening social capital, sustainable development of human resources, and helping vulnerable groups through developing equal opportunities are examples of good governance goals (Gholipour, 2004). The function of good governance depends on the results of its application, and several views have been stated in this regard. The United Nations enumerates a wide range of results, the main of which are: prioritizing poverty issues, increasing awareness for women's rights, protecting the environment, providing the necessary opportunities for employment and other welfare issues, increasing the productivity of organizations and institutions in the society and economic growth (Bayeh, 2016). In another study, the features of good governance have been mentioned that are based on the results. These features include strengthening democratic structures, increasing transparency, responsiveness, and participation development, creating a new discourse regarding the respect for human rights and the governance of law, developing and adopting an appropriate economic policy to facilitate development (Huang and Ho, 2017). Another definition of the concept of good governance refers to functions such as the legitimacy of government, accountability of government and citizens and civil society for their decisions and behaviors, efficient management of society in political, cultural, economic, and social dimensions, free flow of information, free and equal participation of all groups, the governance of law and equality before the law, rational monitoring by the government over the society and rational monitoring by the society over the government, reducing inequality and corruption, and impartiality of the government (Börzel and Pamuk, 2012). The results and functions of good governance in various political, 
economic, social, and public sectors are summarized in Table 1.

\subsection{Dimensions of Good Governance}

The United Nations Development Program explains good governance with two goals of economic development and political development. These institutions consider good governance with some features such as transparency, governance of the law, legitimacy, competence, responsiveness, accountability, consensus, strategic vision of the leader and managers. Thus, creating a good government-nation is the basis of good governance (Ciborra and Navarra, 2005). In this sense, good governance should be both in the democracy concern and human rights and concerns for livelihoods and welfare; on the other hand, it can concern for human empowerment and protecting the environment (Bamgbose, 2015).
Good governance has eight main dimensions, including participation, axial consensus, responsiveness, transparency, accountability, efficiency and effectiveness, comprehensiveness, no discrimination among citizens, and the governance of law. Good governance ensures the minimization of corruption and respecting the opinions of minorities and vulnerable groups in making decisions. Moreover, good governance is responsible for the current and future needs of society (Auriacombe and Shikha, 2019).

\subsection{Good Governance Criteria}

It is challenging to study a phenomenon without having its elements and components and a precise and clear definition of each of them. To better understand the concept and dimensions of good governance, at first, it is appropriate to review its criteria. However, these criteria are mentioned in different texts with different numbers and names (Munzhedzi and Makwembere, 2019).

Table 1. The results and functions of good governance

\begin{tabular}{|c|c|c|c|}
\hline & & Civil liberties & Shikha and Aktan (2017) \\
\hline & & Increasing transparency & $\begin{array}{l}\text { Moreno-Albarracín et al. (2020), Valentinov et al. (2019), Devaney } \\
\text { (2016), De Graaf and Paanakker (2015), Biondi and Lapsley } \\
\text { (2014), Carlitz (2013) }\end{array}$ \\
\hline & Political & Enhancing accountability & $\begin{array}{l}\text { Brinkerhoff (2017), Devaney (2016), Kardos (2012), Almqvist et } \\
\text { al. (2012) }\end{array}$ \\
\hline & & $\begin{array}{l}\text { Legitimacy of the } \\
\text { government }\end{array}$ & DeRouen and Goldfinch (2012), Christensen and Lægreid (2020) \\
\hline & & Correct electoral system & Lucky (2014), Doorenspleet and Pellikaan (2013) \\
\hline & & Independent and free media & $\begin{array}{l}\text { Dunu (2013), Khazaeli and Stockemer (2013), Hassid and Brass } \\
\text { (2015) }\end{array}$ \\
\hline & & $\begin{array}{l}\text { Equal employment } \\
\text { opportunities }\end{array}$ & $\begin{array}{l}\text { Alam and Alam (2014), Munzhedzi and Makwembere (2019), } \\
\text { Keping (2018) }\end{array}$ \\
\hline & & Enhancing productivity & $\begin{array}{l}\text { Khan (2012), Krammer (2015), Fayissa and Nsiah (2013), Bayeh } \\
(2016),\end{array}$ \\
\hline 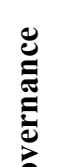 & Economic & Economic growth & $\begin{array}{l}\text { Fayissa and Nsiah (2013), Khan (2012), Careaga and Weingast } \\
\text { (2012), Fayissa and Nsiah (2013), Mira and Hammadache (2017), } \\
\text { Raza et al (2019), Huang and Ho (2017), Méndez-Picazo et al. } \\
(2012)\end{array}$ \\
\hline$\stackrel{0}{\mathscr{O}_{0}}$ & & Reducing inequalities & $\begin{array}{l}\text { Méndez-Picazo et al. (2012), Kwon and Kim (2014), Hegre and } \\
\text { Nygård (2015), Dauda (2017) }\end{array}$ \\
\hline$\frac{80}{0}$ & & $\begin{array}{l}\text { Financial and monetary } \\
\text { transparency }\end{array}$ & $\begin{array}{l}\text { Carlitz (2013), Dunu (2013), Ofoegbu (2014), Mohammed (2012), } \\
\text { Shikha and Aktan (2017) }\end{array}$ \\
\hline 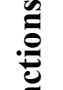 & & Promoting social capital & $\begin{array}{l}\text { Ruben and Heras (2012), Górriz-Mifsud et al. (2016), Rahaman } \\
\text { (2018), Bernstein (2015), Cao et al. (2016) }\end{array}$ \\
\hline$\widehat{\bar{E}}$ & & Social welfare & $\begin{array}{l}\text { Razak and Ali (2020), Juknevičienė and Kareivaitė (2012), Odo } \\
\text { (2015), Massey and Johnston-Miller (2015) }\end{array}$ \\
\hline & Social & Poverty alleviation & $\begin{array}{l}\text { Mwakaje et al. (2013), Hassan et al. (2020), Stojanović et al. } \\
\text { (2016), Bazilian et al. (2014) }\end{array}$ \\
\hline & & Promoting women's right & Bamgbose (2015), Bayeh (2016), Bach-Golecka (2018) \\
\hline & & Protecting the environment & Farag et al. (2013), Cash (2016), \\
\hline & & Effective control of citizens & Keping (2018), Beeri et al. (2019) \\
\hline & & Free flow of information & Nag (2018), Yaghoub (2017), Kaur (2018) \\
\hline & & governance of the law & Zaman (2015), Yousaf et al. (2016), Kraipornsak (2018) \\
\hline & Public & Sustainable development & $\begin{array}{l}\text { Kardos (2012), Osakede et al. (2015), Stojanović et al. (2016), } \\
\text { Raszkowski and Bartniczak (2018), Auriacombe and Shikha 2019), } \\
\text { Ramzy et al. (2019) }\end{array}$ \\
\hline & PuDnc & Efficient management & Kardos (2012), Getzner et al. (2012), Khanna (2017), Giri (2019), \\
\hline & & Enhancing partnership & Asaduzzaman et al. (2016), Keping (2018), Debela (2019) \\
\hline & & $\begin{array}{l}\text { Fight against corruption } \\
\text { Proper control and } \\
\text { monitoring }\end{array}$ & $\begin{array}{l}\text { Börzel and Pamuk (2012), McCall and Dunn (2012), Mungiu- } \\
\text { Pippidi (2014), Abd Aziz et al. (2015) }\end{array}$ \\
\hline
\end{tabular}


Nowadays, the issue of good governance has been seriously considered by scientific societies. In fact, what is today known as good governance is a type of governance that has such criteria: responsiveness and the right to comment; political stability and absence of violence; government's effectiveness; regulating quality; governance of the law; and corruption inhibition (Kaufmann et al., 2009). This research attempts to provide a hierarchical model of criteria and sub-criteria of good governance in project-based organizations through a systematic review of the literature.

\subsection{Project-Based Organizations}

A project-based organization is an open system composed of individuals developed with specific goals and desires that implements the projects to achieve its goals. However, this is a simple definition of a project-based organization, and there are more precise and scientific definitions, which will be offered in the following.

Several studies point out that a wide range of companies and firms perform their operations through project, project management, and various types of project structures in order to increase the flexibility and integration of knowledge resources. The widespread use of projectbased structures is one of the most evident changes in large European firms in the 1990s. So that the expansion of the use of these structures, change of organizations, and their tendency to become project-based shows implicitly that the project has turned into a common working environment (Bredin, 2008). A project-based organization is a type of organization in which the project is the basic unit of production, creativity, and competition, and there is no formal functional coordination between project lines. Project-based organizations have a wider definition: "The firms in which the project dimensions are superior to other dimensions and do most of their operations in the form of the project" (Lindkvist, 2004). Whitley (2006) believes that project-based organizations usually organize their operations in separate projects. These organizations gather groups with special skills to operate on complex and creative activities; the activities are defined for various goals and/or ordered by different employers.

\subsection{The Characteristics of Project-Based Organizations}

Human et al. (2007) and Turner et al. (2008) consider some characteristics for project-based organizations that distinguish them from other organizations. This group of researchers believes that these characteristics have a close relationship with the human resource management of the organization and challenge it:

- Management through the project is the strategy of a project-based company

- The temporality nature of the project

- Dynamism governing the working environment

- Project portfolio resources and multi-role demands in the working environment

- The specific management paradigm governing these organizations

Each of these characteristics can create specific challenges in the strategic management of human resources in project-based organizations. However, it should be noted that organizations can operate the whole or a part of them as a project (Human et al., 2007). Bredin (2008) also mentions five characteristics for project-based organizations:

- These organizations are knowledge intensity, meaning that knowledge, competency, and skills of employees in this type of organization are the most important factors to enter them.

- In project-based organizations, there is a crossfunctionality for conducting the project; and projects are the result of the integration of competencies along with the functions.

- Projects are temporality. The temporality nature of projects doesn't mean that when the project is completed, the organizations' lifetime is ended.

- There is an inherent tension between the permanent and temporary systems and logic of the organization.

- Due to the temporality of projects, the organization is not supposed to operate weakly in its functions; because the weakness of the organization in its functions makes it not to be able to guarantee the project success and subsequently the organization's success.

Heterogeneity in employment relations is natural in these organizations. In this model of organizing, the relationship between the organization and individuals goes beyond the scope of an individual project.

\subsection{Empirical Research}

Nguyen et al. (2021) conducted research in Vietnam and have sought to answer the question of "do good governance and public administration improve economic growth and poverty reduction?". The results of the data analysis through the province fixed-effect regressions indicated that there is a significant, positive, and nonlinear association between governance and per capita income and public administration. Indeed, the results showed that the better performance of governance and public administration also appears to improve income distribution and reduce poverty. Also, the findings implied that, within a province, better governance and public administration are most beneficial for the poorest of the poor.

Saleh et al. (2021) persuaded the effect of good governance on financial performance. They surveyed 200 local government employees through the questionnaire to assess the effect of transparency, accountability, and participation on financial performance. The results of data analysis showed that transparency has a positive and significant effect on the financial performance of the local government. On the other hand, participation and accountability had no significant effect on the financial performance of the local government.

Omri and Mabrouk (2020) studied the impact of good governance on sustainable development. Using a quantitative approach, the structural equations method, and questionnaire data, they identified three main components of good governance. These components include economic, environmental, and sustainable social components. Their findings show that political governance helps sustainable development and leads to reduced carbon dioxide emission, and there is a two-way relationship between human development and economic growth that can complete each 
other. Therefore, good governance can affect sustainable development components. The most important criteria of good governance include accountability management, communication management, information management, decision-making, cost management, conflicts management, meeting the interests of internal and foreign stakeholders.

Turner (2018) studied the factors affecting project governance. Their findings indicate that the main focus of the project manager during the implementation is on delivering the desired project product and achieving the desired goals of the business, and optimizing time, cost, and quality is of secondary significance. The criteria considered by the researcher to measure the success of project performance are project team satisfaction (with project product users), project completion based on three criteria of time, cost, and quality (stakeholders' satisfaction is the result of realizing these three criteria), and creating value for shareholders. The findings suggest that there should be a balance between the criteria of cost, time, and quality, and project completion in the governance of project-based companies.

Kolbedari et al. (2017) studied the components of desirable governance in large-scale multi-organizational projects of civil participation in the large-scale Iranian oil projects (South Pars). Its main strategic outcomes, including governance components consisting of structure, process, and then governance mechanisms of goal management, procurement management, information management, communication, knowledge and learning management, decision-making processes, cost management, conflicts, change management, and stakeholder management are the constituent categories of the process component of governance. The third identified component includes monitoring and control, inspection, audit, and evaluation of governance mechanisms affecting the participation performance of large-scale projects in the oil industry.

Chandra and Yokoyama (2011) studied the role of good governance on the growth of a knowledge-based economy. The findings of this study show that the criteria of good governance and their role in attracting foreign investors have a positive impact on the improvement and enhancement of knowledge-based economy in the selected countries. The most important criteria of good governance in this study include meeting the interests of foreign stakeholders identified by government managers and experienced consultants in the public organizations of east Asian countries.

Waheduzzaman (2010) in an article entitled "The value of people's participation for good governance in developing countries," studied the issue of good governance. He concluded that effective participation of people leads to development through creating an accountable, legal, and transparent government or good governance.

Ho et al. (2009) studied the governance structure and the governance of participatory projects in the construction industry. The population of this research was composed of project managers, investors, executives, and experts. Considering the governance structure and the governance of participatory projects in the construction industry, two governance structures have been identified: 1- collective management of participation, and 2- separate management of participation. According to the researchers, in fact, the governance structure of participation will be between these two categories. In addition, components and factors such as differences in organizational culture, trust, motivation to learn, and the need for procurement affect the selection of each of these structures. The most important criteria of good governance in the mentioned project include information management, communication management, knowledge, and learning management.

As can be seen, all mentioned studies in the field of good governance are related to governmental, national, or international organizations. Each of the previous researches using different quantitative and qualitative methods has tried to explain the role of good governance in improving performance. However, none of the previous studies have addressed the issue of good governance in private or project-based organizations, and there is a gap for such research in the good governance literature. Therefore, the purpose of this study is to develop good governance literature into private and project-based organizations so that they can improve their performance by considering the principles of good governance in their activities.

\section{Research Methodology}

In the present research, a combined approach composed of three methods of meta-synthesis, thematic analysis, and BWM has been used to identify and rank the criteria of good governance. The first phase of the research was a qualitative phase that attempted to extract the criteria of good governance from the literature using the seven-step model of Sandowski and Barroso (2006). Then, using the thematic analysis, the interviews of 10 experts in the field of research were analyzed. The statistical population of the first phase of research was included ten experts from project-based organizations with at least ten years of related experiences and with an education of higher than master's degree. In order to select the experts, the snowball sampling method was used, and this sampling process continued until the theoretical saturation was reached. Finally, a list of criteria of good governance in projectbased organizations was prepared by gathering the extracted criteria from literature and experts. Then, they were ranked using BWM. The research population in the first phase included all research articles published in reputable journals from 2012 to 2020 . The steps related to each of these methods are presented in the following.

The steps of the meta-synthesis method (Sandowski and Barroso, 2006):

- Step 1: developing the research question

- Step 2: systematic literature review

- Step 3: search and select the appropriate articles

- Step 4: extracting the results

- Step 5: analyze and combine qualitative findings and model extraction

- Step 6: quality control

- Step 7: presenting the findings

The steps of the thematic analysis method (Clarke and Braun, 2014):

- Step 1: analyze and describe the text

- Step 2: explain and interpret the text

- Step 3: combine and integrate the text

The steps of the BWM method (Rezaei, 2016): 
- Step 1: determine a set of decision criteria

- Step 2: determine the best (the most important/the most desirable) and the worst (the least important/ the least desirable) criteria

- Step 3: determine the preferred amount of the best/the most important criteria compared to other criteria using numbers 1 to 9

- Step 4: determine the preferred amount of other criteria compared to the worst/the least important criteria using numbers 1 to 9

- Step 5: determine the optimal weights of criteria

\section{Data Analysis}

\subsection{Meta-Synthesis Method}

In this section, we extract the criteria of good governance from the literature using the meta-synthesis method and through the following steps:

\section{Step 1: Developing the research question}

The first question to start the meta-synthesis method is "What?". The main question of the present research is:

"What are the criteria and sub-criteria of good governance in project-based organizations?"

\section{Step 2: Systematic review of literature}

In this step of research, we systematically search the articles published in various scientific journals. The related keywords are selected. The searched keywords in the domestic and foreign scientific databases are presented in Table 2. These keywords have been selected according to the first research question to find the conducted research in the field of good governance, not only as a characteristic of a nation and country's political system but also as a characteristic of the private and project-based organizations.
Table 2. The keywords searched in the scientific databases

\begin{tabular}{l}
\hline \multicolumn{1}{c}{ Keywords } \\
\hline Good governance \\
\hline Criteria of good governance in the organization \\
\hline Factors affecting good governance in the organization \\
\hline Good governance in a project-based organization \\
\hline Ranking the good governance criteria \\
\hline Good governance in construction companies \\
\hline Good governance in companies \\
\hline
\end{tabular}

\section{Step three: Search and select the appropriate articles}

At the beginning of the search process, the researcher determines whether the articles are relevant to the research question. The tool usually used to evaluate the quality of the initial study of the qualitative research is CASP critical appraisal method. Thus, the articles were evaluated and scored based on ten criteria/questions presented in Table 3. The maximum score of each question/criterion was considered 5. Then, the sum of the scores each article earned based on the ten criteria was calculated. Finally, the articles whose total score was less than 25 were removed. Accordingly, as can be seen in Fig. 1, after filtering the articles through the CASP tool and based on achieving theoretical saturation, the final number of articles was 49

\section{Step four: Extract results}

After selecting the documents and reports, it is time to extract the codes from the texts. To extract the codes, the research question was taken into account. The question of the present research is:

"What are the criteria and sub-criteria of good governance in project-based organizations?"

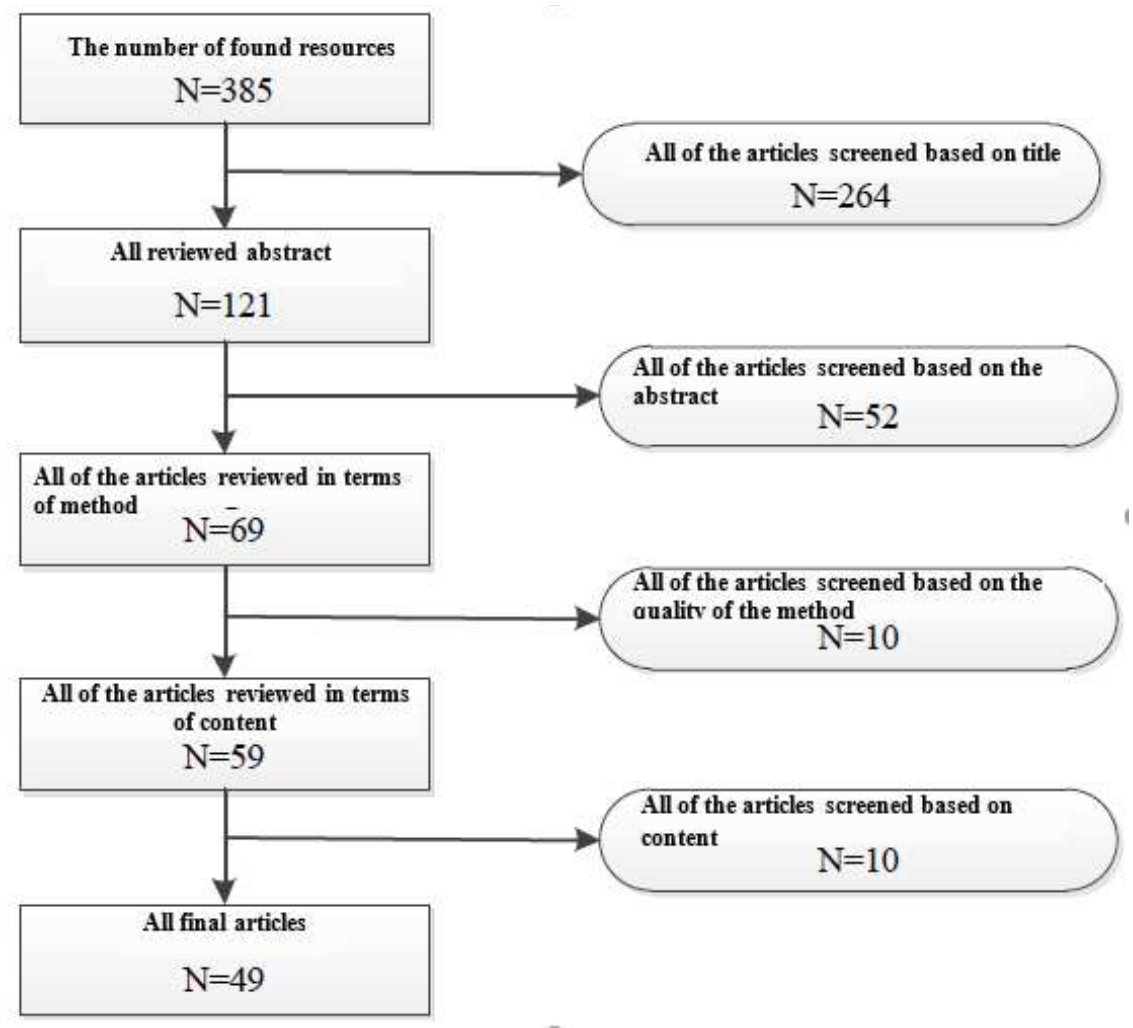

Fig. 1. The process of screening the articles using CASP methodology 


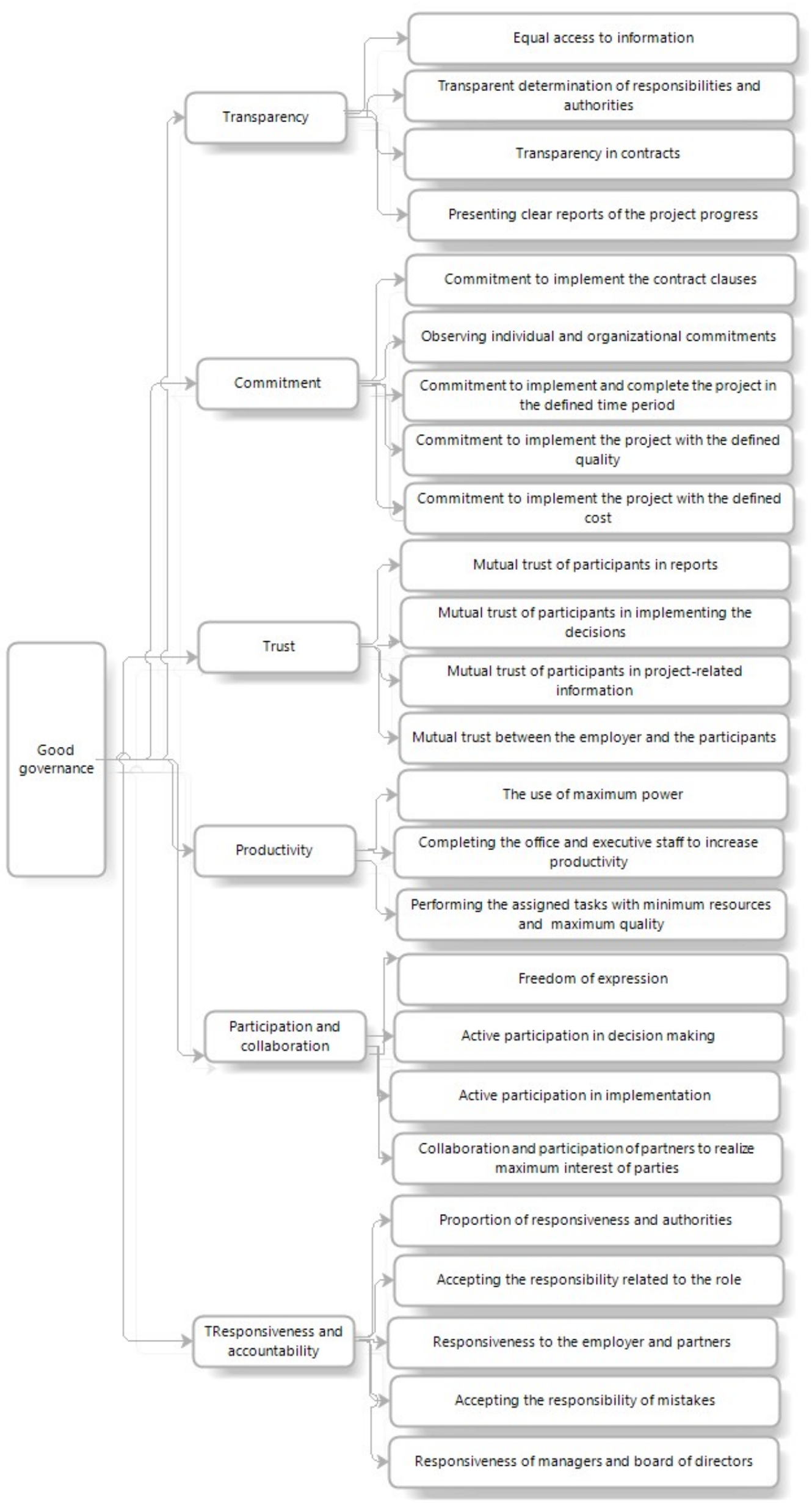

Fig 2. The hierarchical model of criteria and sub-criteria of good governance 
Table 3. Questions/criteria of evaluating the articles through CASP methodology

\begin{tabular}{|c|c|c|}
\hline Row & Question title & Question description \\
\hline 1 & $\begin{array}{l}\text { Research } \\
\text { goals }\end{array}$ & $\begin{array}{l}\text { Are the selected articles in line } \\
\text { with the desired research? }\end{array}$ \\
\hline 2 & $\begin{array}{l}\text { Research } \\
\text { design }\end{array}$ & $\begin{array}{l}\text { Are the articles designed } \\
\text { appropriately? }\end{array}$ \\
\hline 3 & $\begin{array}{l}\text { Sampling } \\
\text { method }\end{array}$ & $\begin{array}{l}\text { Are the article's population, } \\
\text { statistical sample, and } \\
\text { sampling method appropriate? }\end{array}$ \\
\hline 4 & $\begin{array}{l}\text { Data } \\
\text { collection }\end{array}$ & $\begin{array}{l}\text { Are the sources and method of } \\
\text { data collection appropriate? }\end{array}$ \\
\hline 5 & Reflectivity & $\begin{array}{l}\text { What is the capability to } \\
\text { generalize the points in the } \\
\text { selected articles? }\end{array}$ \\
\hline 6 & $\begin{array}{l}\text { Accuracy in } \\
\text { data analysis }\end{array}$ & $\begin{array}{l}\text { How is the accuracy in data } \\
\text { analysis and the method used } \\
\text { for data analysis? }\end{array}$ \\
\hline 7 & $\begin{array}{l}\text { Clear } \\
\text { expression of } \\
\text { findings }\end{array}$ & $\begin{array}{l}\text { Is the transparency and } \\
\text { eloquence of the article } \\
\text { appropriate? }\end{array}$ \\
\hline 8 & $\begin{array}{l}\text { Ethical } \\
\text { considerations }\end{array}$ & $\begin{array}{l}\text { Are the ethical principles of } \\
\text { writing an article such as } \\
\text { inserting references etc., } \\
\text { observed in this article? }\end{array}$ \\
\hline 9 & $\begin{array}{l}\text { Being up to } \\
\text { date }\end{array}$ & $\begin{array}{l}\text { Is the article up to date in terms } \\
\text { of subject and method? }\end{array}$ \\
\hline 10 & $\begin{array}{l}\text { Research } \\
\text { value }\end{array}$ & $\begin{array}{l}\text { Generally, how do you } \\
\text { evaluate the selected article? }\end{array}$ \\
\hline
\end{tabular}

Step five: Analyze and combine the qualitative findings and model extraction

In the present study, after reviewing 49 final articles, 25 codes/criteria and 6 concepts/criteria were extracted and categorized as the criteria and sub-criteria of desirable governance.

\section{Step six: Quality control}

In qualitative research, quality control means examining the reliability and validity of the research. Validity refers to concepts such as defensibility, believability, verifiability, and flexibility of the research results. The validity of the research has been confirmed by academician experts. To assess the reliability of the research Cohen's Kappa coefficient was used. Cohen's Kappa coefficient is one of the commonly used methods to measure the agreement between two raters (Gross, 1986). In the present research, the whole research process from research goal-setting and include and exclude criteria to open and axial coding process was evaluated by two academician experts based on 10 questions with a four-option scale $(1=$ poor, $2=$ medium, $3=$ good, $4=$ excellent). Judgmental sampling has been used to select the experts with sufficient knowledge and experience in both fields of this study and the qualitative coding process. Then, the agreement coefficient between the experts' opinions was calculated by Kappa coefficient using SPSS software. As Table 4 shows, Cohen's Kappa coefficient is 0.706 , which indicates the desirable validity of the research results.

\section{Step seven: Presenting the findings}

The model presented in Fig. 2 is introduced as the hierarchical model of criteria and sub-criteria of good governance.

\subsection{Thematic Analysis Method}

The purpose of this section is to identify and extract the criteria of good governance in project-based organizations and from the perspective of experts in this field. For this aim, we interviewed ten experts in this field who had the necessary knowledge on the project subject and criteria of good governance. Then, the text of interviews extracted the criteria of participants using the thematic analysis method and in three steps introduced in section three. The analysis of interviews led to identifying 92 codes/sub-criteria in the form of 10 categories/criteria as the criteria of good governance. Fig. 3 shows the output of super words of ATLAS.ti software. As can be seen, the codes of responsiveness, trust, and transparency, respectively, with 50,49 , and 48 repetitions, were among the most frequently used words by the interview. This issue shows the significance of these criteria in the governance of projectbased organizations. The final list of criteria and subcriteria of good governance extracted from literature and interview with experts, which include 98 sub-criteria, is presented in Table 5.

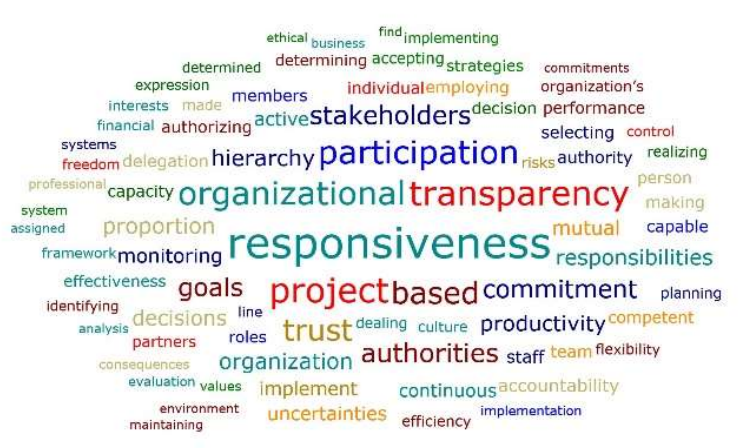

Fig. 3. The output of ALTAS.ti software: super words at the level of criteria and sub-criteria of good governance

\subsection{BWM Method}

In this section, the criteria of good governance in projectbased organizations were weighed and ranked using the BWM method and based on the consensus opinion of experts. Table 6 shows the results of this weighing and prioritizing.

Table 4. The agreement coefficient between the experts

\begin{tabular}{|c|c|c|c|c|c|}
\hline \multicolumn{6}{|c|}{ Symmetric Measures } \\
\hline & & Value & $\begin{array}{c}\text { Asymp. } \\
\text { Std. Error }\end{array}$ & $\begin{array}{c}\text { Approx } \\
. \mathrm{T}^{\mathrm{b}}\end{array}$ & $\begin{array}{l}\text { Approx. } \\
\text { Sig. }\end{array}$ \\
\hline Measure of Agreement & Kappa & .706 & .172 & 3.594 & .000 \\
\hline $\mathrm{N}$ of Valid Cases & & 10 & & & \\
\hline \multicolumn{6}{|c|}{ a. Not assuming the null hypothesis. } \\
\hline
\end{tabular}


Table 5. The final list of criteria and sub-criteria of good governance

\begin{tabular}{|c|c|c|c|}
\hline \multirow[t]{2}{*}{ Category } & Concept/criteria & Code/sub-criteria & Source \\
\hline & \multirow[t]{14}{*}{ Transparency } & Transparent reports of project progress & Literature \\
\hline \multirow{54}{*}{ 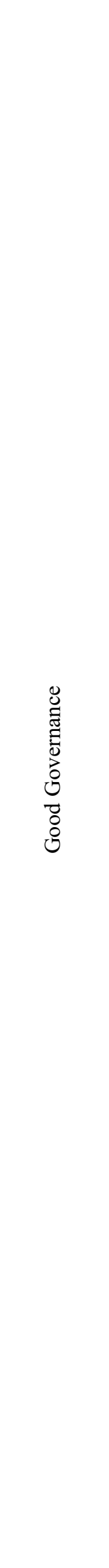 } & & Transparency in presenting the weaknesses and risks & Experts \\
\hline & & Transparency in project goals & Experts \\
\hline & & Transparency in decisions & Experts \\
\hline & & Transparency in determining roles and responsibilities and authorities & Literature \\
\hline & & Transparency in processes and instructions & Experts \\
\hline & & Transparency in contracts & Literature \\
\hline & & Transparency in feasibility studies & Experts \\
\hline & & Legal transparency & Experts \\
\hline & & Financial and performance transparency & Experts \\
\hline & & Transparency in selecting the project elements & Experts \\
\hline & & Resolving the ambiguity of staff & Experts \\
\hline & & The process of regular reporting & Experts \\
\hline & & Equal access to information & Literature \\
\hline & \multirow[t]{9}{*}{ Commitment } & Executive commitment of experts & Experts \\
\hline & & $\begin{array}{l}\text { Commitment to implement the project in the framework of organization's } \\
\text { goals }\end{array}$ & Experts \\
\hline & & Commitment to implement the project with the determined quality & Literature \\
\hline & & Commitment to value creation & Experts \\
\hline & & Legal commitment & Experts \\
\hline & & Commitment to implement the contract clauses & Literature \\
\hline & & Observing individual and organizational commitments & Literature \\
\hline & & $\begin{array}{l}\text { Commitment to implement and complete the project in the determined } \\
\text { time period }\end{array}$ & Literature \\
\hline & & Commitment to implement the project with the determined cost & Literature \\
\hline & \multirow[t]{9}{*}{ Trust } & CEO's trust in the project manager & Experts \\
\hline & & Mutual trust between the employer and partners & Literature \\
\hline & & Trust in contracts & Experts \\
\hline & & Building trust-based on honesty & Experts \\
\hline & & Mutual trust between the partners in reporting & Literature \\
\hline & & Mutual trust between the partners in implementing the made decisions & Literature \\
\hline & & Mutual trust between the partners in project-related information & Literature \\
\hline & & Rebuilding and compensating the lost trust & Experts \\
\hline & & Obtaining and maintaining the stakeholders' trust & Experts \\
\hline & \multirow{16}{*}{$\begin{array}{l}\text { Productivity } \\
\text { (efficiency and } \\
\text { effectiveness) }\end{array}$} & The effectiveness of individuals' work per unit of time & Experts \\
\hline & & Optimal use of available resources & Experts \\
\hline & & Productivity in human resources, machinery, and equipment & Experts \\
\hline & & Productivity proportional to the assigned tasks in the contract & Experts \\
\hline & & Continuous monitoring of the external environment to find opportunities & Experts \\
\hline & & Continuous monitoring of the internal environment to find the strengths & Experts \\
\hline & & The impact of external factors governing the country & Experts \\
\hline & & Business analysis & Experts \\
\hline & & Continuous analysis and monitoring of business by project team & Experts \\
\hline & & Proportion between overhead costs and operational costs of the project & Experts \\
\hline & & Compensating financial damages & Experts \\
\hline & & Employing and selecting competent and capable staff & Experts \\
\hline & & Completing the office and executive staff to increase productivity & Literature \\
\hline & & Individual and organizational performance evaluation system & Experts \\
\hline & & Identifying the factors enhancing productivity & Experts \\
\hline & & Continuous monitoring and inspection & Experts \\
\hline & \multirow[t]{7}{*}{ Participation } & Participation of project team members in implementation & Literature \\
\hline & & Active participation in decision making & Literature \\
\hline & & Participation in feasibility studies & Experts \\
\hline & & $\begin{array}{l}\text { Participation in realizing the project goals in line with the interests of } \\
\text { stakeholders }\end{array}$ & Literature \\
\hline & & Participation of domestic stakeholders in planning & Experts \\
\hline & & Participation of policy makers and executives & Experts \\
\hline & & Active participation of project team and organization members & Experts \\
\hline
\end{tabular}


Table 5. The final list of criteria and sub-criteria of good governance (continued)

\begin{tabular}{|c|c|c|c|}
\hline Category & Concept/criteria & Code/sub-criteria & Source \\
\hline \multirow{43}{*}{ 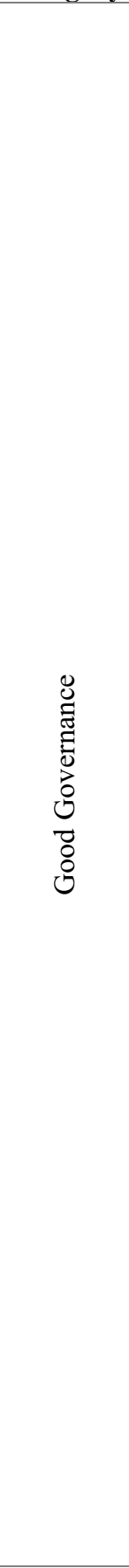 } & \multirow[t]{3}{*}{ Participation } & A participatory model appropriate for stakeholders & Experts \\
\hline & & Participatory management & Experts \\
\hline & & Freedom of expression & Literature \\
\hline & \multirow{13}{*}{$\begin{array}{l}\text { Responsiveness } \\
\text { and } \\
\text { accountability }\end{array}$} & Responsiveness based on organizational hierarchy & Experts \\
\hline & & Responsiveness to monitoring systems & Experts \\
\hline & & Responsiveness to key stakeholders & Experts \\
\hline & & Responsiveness for made decisions & Experts \\
\hline & & Managers and director board members' responsiveness & Literature \\
\hline & & Proportion of responsiveness and authorities & Literature \\
\hline & & Responsiveness to organization's guard & Experts \\
\hline & & Accepting the responsibility of mistakes and failures & Literature \\
\hline & & Accepting the consequences of decisions & Experts \\
\hline & & Accepting the responsibility of assigned roles & Literature \\
\hline & & Accountability of project team in realizing the project goals & Experts \\
\hline & & Professional responsibilities & Experts \\
\hline & & Social responsibilities & Experts \\
\hline & \multirow{5}{*}{$\begin{array}{l}\text { Delegation of } \\
\text { authority }\end{array}$} & Authorizing based on the capacity of each person & Experts \\
\hline & & Periodic review of authorities & Experts \\
\hline & & Delegation of authority at the level of senior managers & Experts \\
\hline & & Delegation of authority based on organization hierarchy & Experts \\
\hline & & Proportion of responsibilities with authorities & Experts \\
\hline & \multirow{10}{*}{$\begin{array}{l}\text { Organizational } \\
\text { culture }\end{array}$} & Ethical considerations & Experts \\
\hline & & Value creation & Experts \\
\hline & & Organizational values according to the culture of each region & Experts \\
\hline & & Evaluating the project achievements based on organizational values & Experts \\
\hline & & Informing organizational values & Experts \\
\hline & & Adherence to implicit and explicit ethical principles & Experts \\
\hline & & Promoting organizational culture supporting positive changes and enablers & Experts \\
\hline & & The growth of professional ethics in the organization & Experts \\
\hline & & Complete observation of individual and organizational disciplines & Experts \\
\hline & & Verifying the organizational values & Experts \\
\hline & \multirow{8}{*}{$\begin{array}{l}\text { Goals and } \\
\text { strategies }\end{array}$} & Alignment of strategies and goals with CASP & Experts \\
\hline & & Identifying and understanding the needs of stakeholders & Experts \\
\hline & & Continuous and updated control and monitoring mechanism & Experts \\
\hline & & Involvement of project team members in business analysis & Experts \\
\hline & & Understanding the basic capabilities and challenges & Experts \\
\hline & & Strategy development & Experts \\
\hline & & Planning and determining the strategies and goals & Experts \\
\hline & & Continuous planning, implementation, and control of outputs & Experts \\
\hline & \multirow{4}{*}{$\begin{array}{c}\text { Risk and } \\
\text { uncertainties } \\
\text { management }\end{array}$} & Identifying risks and uncertainties & Experts \\
\hline & & Flexibility in dealing with uncertainties & Experts \\
\hline & & Planning to respond to risks and uncertainties & Experts \\
\hline & & Organization's agility in decision making and implementation & Experts \\
\hline
\end{tabular}

As Table 6 shows, the results of weighting the criteria indicate that according to the experts, sub-criteria of planning to respond to uncertainties and risks in the risk and uncertainties management category with a weight of 0.03880 is the most important sub-criteria of good governance in project-based organizations. Following that, sub-criteria of social responsibility and proportion of responsiveness and accountability with weights of 0.03878 and 0.03421 are in the second and third ranks.

\section{Conclusion}

The present research aims to identify and prioritize the criteria of good governance in project-based organizations. For this purpose, a combined approach composed of three methods of meta-synthesis, thematic analysis, and BWM was used. At first, the meta-synthesis method was used to extract the criteria of good governance from the literature. Finally, 25 codes in the form of 6 concepts were extracted. Then, using the thematic analysis method, the interviews with experts were analyzed. The output of this section was 92 codes extracted in the form of 10 concepts. Then, by gathering the codes extracted from the meta-synthesis method and thematic analysis, a total of 98 codes were selected and studied in the form of 10 concepts as final criteria. Finally, using the BWM method, the identified criteria were weighted and ranked. The results of weighting indicated that the responsiveness and accountability criteria are the most important criteria of research among the ten criteria of good governance. Out of 98 sub-criteria, planning to respond to uncertainties and risks, social responsibility, and proportion of responsiveness and authorities were the first to third subcriteria of this research. 
Table 6. Final weight and priority of sub-criteria of the research

\begin{tabular}{|c|c|c|c|c|}
\hline Category & Criteria & Sub-criteria & $\begin{array}{c}\text { Final } \\
\text { weight }\end{array}$ & Rank \\
\hline \multirow{51}{*}{ 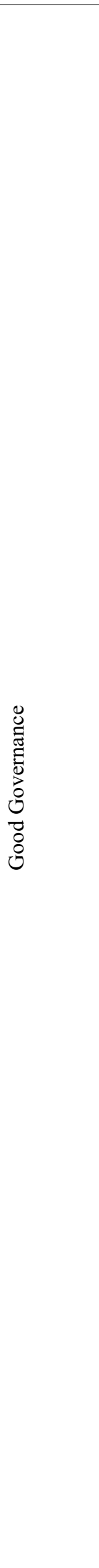 } & \multirow[t]{14}{*}{ Transparency } & Transparent reports of project progress & 0.00561 & 66 \\
\hline & & Transparency in presenting the weaknesses and risks & 0.00485 & 72 \\
\hline & & Transparency in project goals & 0.00843 & 45 \\
\hline & & Transparency in decisions & 0.01271 & 27 \\
\hline & & $\begin{array}{l}\text { Transparency in determining roles and responsibilities and } \\
\text { authorities }\end{array}$ & 0.01082 & 33 \\
\hline & & Transparency in processes and instructions & 0.00197 & 94 \\
\hline & & Transparency in contracts & 0.01030 & 37 \\
\hline & & Transparency in feasibility studies & 0.00987 & 39 \\
\hline & & Legal transparency & 0.00439 & 77 \\
\hline & & Financial and performance transparency & 0.01781 & 12 \\
\hline & & Transparency in selecting the project elements & 0.00689 & 53 \\
\hline & & Resolving the ambiguity of staff & 0.00499 & 70 \\
\hline & & The process of regular reporting & 0.00366 & 83 \\
\hline & & Equal access to information & 0.00582 & 64 \\
\hline & \multirow[t]{9}{*}{ Commitment } & Executive commitment of experts & 0.0335 & 4 \\
\hline & & $\begin{array}{l}\text { Commitment to implement the project in the framework of } \\
\text { organization's goals }\end{array}$ & 0.00915 & 41 \\
\hline & & Commitment to implement the project with the determined quality & 0.01497 & 20 \\
\hline & & Commitment to value creation & 0.00556 & 67 \\
\hline & & Legal commitment & 0.00309 & 87 \\
\hline & & Commitment to implement the contract clauses & 0.01270 & 28 \\
\hline & & Observing individual and organizational commitments & 0.00866 & 44 \\
\hline & & $\begin{array}{l}\text { Commitment to implement and complete the project in the } \\
\text { determined time period }\end{array}$ & 0.00771 & 48 \\
\hline & & Commitment to implement the project with the determined cost & 0.00537 & 69 \\
\hline & \multirow{9}{*}{ Trust } & CEO's trust in the project manager & 0.00403 & 80 \\
\hline & & Mutual trust between the employer and partners & 0.00204 & 93 \\
\hline & & Trust in contracts & 0.00084 & 98 \\
\hline & & Building trust based on honesty & 0.00425 & 79 \\
\hline & & Mutual trust between the partners in reporting & 0.00144 & 97 \\
\hline & & $\begin{array}{l}\text { Mutual trust between the partners in implementing the made } \\
\text { decisions }\end{array}$ & 0.00324 & 85 \\
\hline & & Mutual trust between the partners in project-related information & 0.00151 & 96 \\
\hline & & Rebuilding and compensating the lost trust & 0.00233 & 91 \\
\hline & & Obtaining and maintaining the stakeholders' trust & 0.00543 & 68 \\
\hline & \multirow{16}{*}{$\begin{array}{l}\text { Productivity } \\
\text { (efficiency and } \\
\text { effectiveness) }\end{array}$} & The effectiveness of individuals' work per unit of time & 0.01164 & 30 \\
\hline & & Optimal use of available resources & 0.02043 & 11 \\
\hline & & Productivity in human resources, machinery, and equipment & 0.01074 & 34 \\
\hline & & Productivity proportional to the assigned tasks in the contract & 0.00706 & 50 \\
\hline & & $\begin{array}{l}\text { Continuous monitoring of the external environment to find } \\
\text { opportunities }\end{array}$ & 0.00803 & 46 \\
\hline & & $\begin{array}{l}\text { Continuous monitoring of the internal environment to find the } \\
\text { strengths }\end{array}$ & 0.00632 & 62 \\
\hline & & The impact of external factors governing the country & 0.00649 & 59 \\
\hline & & Business analysis & 0.00455 & 75 \\
\hline & & Continuous analysis and monitoring of business by project team & 0.00704 & 51 \\
\hline & & $\begin{array}{l}\text { Proportion between overhead costs and operational costs of the } \\
\text { project }\end{array}$ & 0.00397 & 81 \\
\hline & & Compensating financial damages & 0.01355 & 25 \\
\hline & & Employing and selecting competent and capable staff & 0.02803 & 6 \\
\hline & & Completing the office and executive staff to increase productivity & 0.00702 & 52 \\
\hline & & Individual and organizational performance evaluation system & 0.01013 & 38 \\
\hline & & Identifying the factors enhancing productivity & 0.01420 & 23 \\
\hline & & Continuous monitoring and inspection & 0.00793 & 47 \\
\hline & \multirow[t]{3}{*}{ Participation } & Participation of project team members in implementation & 0.00668 & 58 \\
\hline & & Active participation in decision making & 0.01747 & 13 \\
\hline & & Participation in feasibility studies & 0.01395 & 24 \\
\hline
\end{tabular}


Table 6. Final weight and priority of sub-criteria of the research (continued)

\begin{tabular}{|c|c|c|c|c|}
\hline Category & Criteria & Sub-criteria & $\begin{array}{l}\text { Final } \\
\text { weight }\end{array}$ & Rank \\
\hline & & $\begin{array}{l}\text { Participation in realizing the project goals in line with the interests } \\
\text { of stakeholders }\end{array}$ & 0.01041 & 36 \\
\hline & & Participation of domestic stakeholders in planning & 0.00681 & 56 \\
\hline & & Participation of policy makers and executives & 0.00240 & 90 \\
\hline & & Active participation of project team and organization members & 0.00670 & 57 \\
\hline & & A participatory model appropriate for stakeholders & 0.00636 & 61 \\
\hline & & Participatory management & 0.00594 & 63 \\
\hline & & Freedom of expression & 0.01148 & 31 \\
\hline & \multirow{13}{*}{$\begin{array}{l}\text { Responsiveness } \\
\text { and } \\
\text { accountability }\end{array}$} & Responsiveness based on organizational hierarchy & 0.00647 & 60 \\
\hline & & Responsiveness to monitoring systems & 0.01046 & 35 \\
\hline & & Responsiveness to key stakeholders & 0.01647 & 18 \\
\hline & & Responsiveness for made decisions & 0.02421 & 7 \\
\hline & & Managers and director board members' Responsiveness & 0.01111 & 32 \\
\hline & & Proportion of responsiveness and authorities & 0.03421 & 3 \\
\hline & & Responsiveness to organization's guard & 0.005820 & 65 \\
\hline & & Accepting the responsibility of mistakes and failures & 0.01211 & 29 \\
\hline & & Accepting the consequences of decisions & 0.01650 & 17 \\
\hline & & Accepting the responsibility of assigned roles & 0.01729 & 14 \\
\hline & & Accountability of project team in realizing the project goals & 0.01590 & 19 \\
\hline & & Professional responsibilities & 0.01729 & 15 \\
\hline & & Social responsibilities & 0.03878 & 2 \\
\hline & \multirow{5}{*}{$\begin{array}{l}\text { Delegation of } \\
\text { authorities }\end{array}$} & Authorizing based on the capacity of each person & 0.02123 & 8 \\
\hline & & Periodic review of authorities & 0.01472 & 22 \\
\hline & & Delegation of authority at the level of senior managers & 0.00837 & 43 \\
\hline & & Delegation of authority based on organization hierarchy & 0.00490 & 71 \\
\hline & & Proportion of responsibilities with authorities & 0.02046 & 10 \\
\hline & \multirow{10}{*}{$\begin{array}{l}\text { Organizational } \\
\text { culture }\end{array}$} & Ethical considerations & 0.00732 & 49 \\
\hline & & Value creation & 0.00440 & 76 \\
\hline & & Organizational values according to the culture of each region & 0.00311 & 86 \\
\hline & & Evaluating the project achievements based on organizational values & 0.00425 & 78 \\
\hline & & Informing organizational values & 0.00299 & 88 \\
\hline & & Adherence to implicit and explicit ethical principles & 0.01681 & 16 \\
\hline & & $\begin{array}{l}\text { Promoting organizational culture supporting positive changes and } \\
\text { enablers }\end{array}$ & 0.00685 & 54 \\
\hline & & The growth of professional ethics in the organization & 0.00484 & 73 \\
\hline & & Complete observation of individual and organizational disciplines & 0.00274 & 89 \\
\hline & & Verifying the organizational values & 0.00163 & 95 \\
\hline & \multirow{8}{*}{$\begin{array}{l}\text { Goals and } \\
\text { strategies }\end{array}$} & Alignment of strategies and goals with CASP & 0.00905 & 42 \\
\hline & & Identifying and understanding the needs of stakeholders & 0.0148 & 21 \\
\hline & & Continuous and updated control and monitoring mechanism & 0.00683 & 55 \\
\hline & & Involvement of project team members in business analysis & 0.00206 & 92 \\
\hline & & Understanding the basic capabilities and challenges & 0.00467 & 74 \\
\hline & & Strategy development & 0.00339 & 84 \\
\hline & & Planning and determining the strategies and goals & 0.00366 & 82 \\
\hline & & Continuous planning, implementation, and control of outputs & 0.01322 & 26 \\
\hline & \multirow{4}{*}{$\begin{array}{l}\text { Risks and } \\
\text { uncertainties } \\
\text { management }\end{array}$} & Identifying risks and uncertainties & 0.02075 & 9 \\
\hline & & Flexibility in dealing with uncertainties & 0.00983 & 40 \\
\hline & & Planning to respond to risks and uncertainties & 0.03880 & 1 \\
\hline & & Organization's agility in decision making and implementation & 0.03152 & 5 \\
\hline
\end{tabular}

Good governance is a relatively emerging phenomenon in the domestic research literature, which has recently been considered by researchers. Therefore, there is no sufficient understanding of concepts and the impact of good governance on organizations' success. Thus, the current study will greatly enrich the research literature in this field by collecting, integrating, and combining the results of conducted studies. Therefore, it is suggested that managers who intend to take advantage of the benefits of good governance in their activities use the results of this research as a roadmap. Moreover, it is suggested that they try to improve the current status of governance in their organization based on the priority of criteria and subcriteria presented in this research.

\subsection{Managerial Implications}

According to the final results of data analysis, the subcriteria of planning to respond to uncertainties and risks 
from the category of uncertainties and risks management was identified as the most important sub-criteria of good governance in project-based organizations. This issue indicates that the studied organizations always suffer from uncertain conditions and risks affecting the performance of projects. This issue has led managers to the term of risk governance as an essential part of good governance, especially in Iranian project-based organizations, which have been forced to cope with a high level of uncertain conditions. To risk governance, it is suggested that managers and all stakeholders in their strategic planning take all actors, individuals, and institutions, public and private into account to a good deal with risks surrounded by uncertainty, complexity, and ambiguity. Therefore, it is suggested that the managers of other organizations and project managers always think of measures to predict the existing risks and take preventive measures. In addition, they should design some strategies to deal with risky and problematic situations before these risks and dangers turn into a serious crisis. Therefore, it proposes to utilize the power of machine learning techniques for risk prediction. After identifying risks, it is time to assess and prioritize the risks. To this end, multi-criteria decision-making methods can be used in order to prioritize identified risks. Finally, managers can define some effective strategies to manage and eliminate risks one by one based on their importance.

Another important sub-criteria of good governance is social responsibility, which has recently been considered by managers of developed countries. This encounter has fueled a debate regarding the degree and nature of convergence between corporate governance and corporate social responsibility. The more enlightened recognize that there is a clear link between governance and corporate social responsibility and make efforts to link the two. Nowadays, just those organizations will be able to operate and compete that not only do well in their professional responsibilities; but also consider the impacts and consequences of their activities in the society and take into account the public interests. Therefore, it is suggested that managers always consider the social aspect of sustainable development and identify that level of society affected by the activities of their organization and take into account their interests, to prevent the impacts of their mistakes on them and not to consider just their own interests.

According to the experts who participated in the present study, the proportion of responsiveness and authorities has the third rank of significance among 98 subcriteria of good governance and is one of the most important issues that managers should take into account in their governance. One of the problems of governance in project-based organizations is the lack of proportion between responsiveness and authorities. For example, in the event of mistakes or failure, sometimes the individuals are questioned who has no authority and power to prevent the occurrence of mistake or failure. This issue will significantly frustrate the workforce and lead to reduced performance levels and even leaving the organization. On the contrary, it is sometimes observed that the individuals have full authority and power on a specific project that has failed and should be accountable for the failure, but they easily shrug their shoulders and don't accept the responsibility. Therefore, it is suggested that organization managers and project managers consider the proportion of authorities and responsiveness in their governance, and in this way, provide one of the most important requirements for good governance.

\subsection{Limitations and Future Research Directions}

Each project, despite its advantages, suffers from some limitations that require more research to reduce these limitations. The present study is not an exception and requires more research to be completed and improved. This study only presents the criteria of good governance in project-based organizations, and non-project-based organizations are not studied. Therefore, other studies can identify the criteria of good governance in other industries and organizations. Moreover, they can study the significance of relationships between corresponding criteria and sub-criteria in each category through the confirmatory factor analysis method. In this study, after identifying and extracting the criteria of good governance, they were weighted and prioritized. In the quantitative phase of research, conducted by the BWM method, the criteria were considered separate from each other and the relationships and impacts of criteria on each other were ignored. Therefore, it is suggested that future studies determine the relationships between criteria and their impact on each other through methods such as DEMATEL. Then, using the ANP method that considers the relationships between criteria, they can prioritize the criteria of good governance in project-based organizations. Moreover, the grounded theory can be used in the qualitative phase of the study and extract a model of factors affecting good governance. Then, using statistical methods such as Structural Equation Modeling, we can explain the extracted model.

\section{References}

Abd Aziz, M. A., Ab Rahman, H., Alam, M. M., and Said, J. (2015). Enhancement of the accountability of public sectors through integrity system, internal control system and leadership practices: A review study. Procedia Economics and Finance, 28, 163-169.

Abdou, A. M. (2021). Good governance and COVID-19: The digital bureaucracy to response the pandemic (Singapore as a model). Journal of Public Affairs, e2656.

Alam, S. M. and Alam, M. N. (2014). Good governance and employment generation through MGNREGA. International Journal of Economics, Commerce and Management, 2(9), 1-17.

Almqvist, R., Grossi, G., Van Helden, G. J., and Reichard, C. (2013). Public sector governance and accountability. In Critical Perspectives on Accounting, 24(7-8), 479487.

Asaduzzaman, M., Kaivo-oja, J., Stenvall, J., and Jusi, S. (2016). Strengthening local governance in developing countries: Partnership as an alternative approach. Public Organization Review, 16(3), 335-356.

Auriacombe, C. and Shikha, V. D. (2019). Critical considerations for the role of governments in the interface between good governance and sustainable development in developing countries. International Journal of eBusiness and eGovernment Studies, 11(1), 1-15.

Bach-Golecka, D. (2018). The Emerging Right to Good Governance. American Journal of International Law, 112, 89-93.

Bamgbose, O. (2015). Access to justice through clinical legal education: A way forward for good governance 
and development. African Human Rights Law Journal, 15(2), 378-396.

Bayeh, E. (2016). The role of empowering women and achieving gender equality to the sustainable development of Ethiopia. Pacific Science Review B: Humanities and Social Sciences, 2(1), 37-42.

Bazilian, M., Nakhooda, S., and Van de Graaf, T. (2014). Energy governance and poverty. Energy Research and Social Science, 1, 217-225.

Beeri, I., Uster, A., and Vigoda-Gadot, E. (2019). Does performance management relate to good governance? A study of its relationship with citizens' satisfaction with and trust in Israeli local government. Public Performance and Management Review, 42(2), 241279.

Bernstein, L. (2015). Beyond relational contracts: Social capital and network governance in procurement contracts. Journal of Legal Analysis, 7(2), 561-621.

Biondi, L. and Lapsley, I. (2014). Accounting, transparency and governance: the heritage assets problem. Qualitative Research in Accounting and Management.

Börzel, T. A. and Pamuk, Y. (2012). Pathologies of Europeanisation: fighting corruption in the Southern Caucasus. West European Politics, 35(1), 79-97.

Bredin, K. (2008). Human resource management in project-based organisations: challenges, changes, and capabilities (Doctoral dissertation, Linköping University Electronic Press).

Brinkerhoff, D. W. (2017). Accountability and good governance: concepts and issues. In International development governance (pp. 269-287). Routledge.

Cao, J. X., Ding, Y., and Zhang, H. (2016). Social capital, informal governance, and post-IPO firm performance: A study of Chinese entrepreneurial firms. Journal of business ethics, 134(4), 529-551.

Careaga, M. and Weingast, B. R. (2012). Fiscal federalism, good governance, and economic growth in Mexico. In In Search of Prosperity (pp. 399-436). Princeton University Press.

Carlitz, R. (2013). Improving transparency and accountability in the budget process: An assessment of recent initiatives. Development Policy Review, 31, s49s67.

Carlitz, R. (2013). Improving transparency and accountability in the budget process: An assessment of recent initiatives. Development Policy Review, 31, s49s67.

Cash, C. (2016). Good governance and strong political will: Are they enough for transformation?. Land Use Policy, 58, 545-556.

Chandra, D. S. and Yokoyama, K. (2011). The role of good governance in the knowledge-based economic growth of East Asia-A study on Japan, Newly Industrialized Economies, Malaysia and China. Graduate School of Economics, Kyushu University.

Christensen, T. and Lægreid, P. (2020). Balancing governance capacity and legitimacy: how the Norwegian government handled the COVID-19 crisis as a high performer. Public Administration Review, 80(5), 774-779.

Ciborra, C. and Navarra, D. D. (2005). Good governance, development theory, and aid policy: Risks and challenges of e-government in Jordan. Information technology for development, 11(2), 141-159.

Clarke, V. and Braun, V. (2014). Thematic analysis. In Encyclopedia of critical psychology (pp. 1947-1952). Springer, New York, NY.

Dauda, R. S. (2017). Poverty and economic growth in Nigeria: Issues and policies. Journal of Poverty, 21(1), 61-79.

De Graaf, G. and Paanakker, H. (2015). Good governance: Performance values and procedural values in conflict. The American review of public administration, 45(6), 635-652.

Debela, G. Y. (2019). Critical success factors (CSFs) of public-private partnership (PPP) road projects in Ethiopia. International Journal of Construction Management, 1-12.

Delavari, M., Goldust, Y., Aeini, S. (2021). Presenting a hierarchical model of good governance criteria in project-oriented organizations, Sixth National Conference on Humanities and Management Studies, https://civilica.com/doc/1234051

DeRouen Jr, K. and Goldfinch, S. (2012). What makes a state stable and peaceful? good governance, legitimacy and legal-rationality matter even more for low-income countries. Civil Wars, 14(4), 499-520.

Devaney, L. (2016). Good governance? Perceptions of accountability, transparency and effectiveness in Irish food risk governance. Food Policy, 62, 1-10.

Doorenspleet, R. and Pellikaan, H. (2013). Which type of democracy performs best?. Acta Politica, 48(3), 237267.

Dunu, I. (2013). Good governance in Nigeria: What role for the media. European Scientific Journal, 9(32).

Farag, M., Nandakumar, A. K., Wallack, S., Hodgkin, D., Gaumer, G., and Erbil, C. (2013). Health expenditures, health outcomes and the role of good governance. International journal of health care finance and economics, 13(1), 33-52.

Fayissa, B. and Nsiah, C. (2013). The impact of governance on economic growth in Africa. The Journal of Developing Areas, 91-108.

Flyvbjerg, B., Bruzelius, N., and Rothengatter, W. (2003). Megaprojects and risk: An anatomy of ambition. Cambridge University Press.

Getzner, M., Jungmeier, M., and Pfleger, B. (2012). Evaluating management effectiveness of national parks as a contribution to good governance and social learning. Protected Area Management. Rijeka: InTech, 129-148.

Gholipour, R. (2004). Analyse feasible use of Good Governance model in Iraninan state structure. Management Science Quarterly,(Tehran), 17(67), 85-112.

Giri, S. (2019). Obstacles of Civil Service in Public Service Delivery in Nepal: E-Governance for Good Governance. International Journal of Computer Science and Mobile Computing, 8(3), 269-274.

Goodspeed, T., Martinez-Vazquez, J., and Zhang, L. (2011). Public policies and FDI location: Differences between developing and developed countries. FinanzArchiv/Public Finance Analysis, 171-191.

Górriz-Mifsud, E., Secco, L., and Pisani, E. (2016). Exploring the interlinkages between governance and 
social capital: A dynamic model for forestry. Forest Policy and Economics, 65, 25-36.

Gross, S. T. (1986). The kappa coefficient of agreement for multiple observers when the number of subjects is small. Biometrics, 883-893.

Guo, F., Chang-Richards, Y., Wilkinson, S., and Li, T. C. (2014). Effects of project governance structures on the management of risks in major infrastructure projects: A comparative analysis. International Journal of Project Management, 32(5), 815-826.

Hassan, M. S., Bukhari, S., and Arshed, N. (2020). Competitiveness, governance and globalization: What matters for poverty alleviation?. Environment, Development and Sustainability, 22(4), 3491-3518.

Hassid, J. and Brass, J. N. (2015). Scandals, media and good governance in China and Kenya. Journal of Asian and African Studies, 50(3), 325-342.

Hegre, H. and Nygård, H. M. (2015). Governance and conflict relapse. Journal of Conflict Resolution, 59(6), 984-1016.

Ho, S. P., Lin, Y. H., Chu, W., and Wu, H. L. (2009). Model for organizational governance structure choices in construction joint ventures. Journal of construction engineering and management, 135(6), 518-530.

Huang, C. J. and Ho, Y. H. (2017). Governance and economic growth in Asia. The North American Journal of Economics and Finance, 39, 260-272.

Juknevičienè, V. and Kareivaite, R. (2012). Good governance as the instrument for the implementation ofthe sustainable development's conception. Socialiniai tyrimai, (3), 28-42.

Kardos, M. (2012). The reflection of good governance in sustainable development strategies. Procedia-Social and Behavioral Sciences, 58, 1166-1173.

Kaufmann, D., Kraay, A., and Mastruzzi, M. (2009). Governance matters VIII: aggregate and individual governance indicators, 1996-2008. World bank policy research working paper, (4978).

Kaur, R. (2018). Good governance: Concept and its application. Asian Journal of Multidimensional Research (AJMR), 7(3), 47-53.

Keping, Y. (2018). Governance and good governance: A new framework for political analysis. Fudan Journal of the Humanities and Social Sciences, 11(1), 1-8.

Khan, A., Hussain, A., Waris, M., Ismail, I., and Ilyas, M. (2018). Infrastructure project governance: An analysis of public sector project in northern Pakistan. Journal of Governance and Integrity, 1(2), 120-134.

Khan, M. (2012). Governance and growth: History, ideology and methods of proof. Good growth and governance in Africa: rethinking development strategies, 51-79.

Khanna, P. (2017). A conceptual framework for achieving good governance at open and distance learning institutions. Open Learning: The Journal of Open, Distance and E-Learning, 32(1), 21-35.

Khazaeli, S. and Stockemer, D. (2013). The Internet: A new route to good governance. International political science review, 34(5), 463-482.

Kjoer, M. and Kinnerup, K. (2002). Good governance: How does it relate to human rights?. In Human rights and good governance (pp. 1-18). Brill Nijhoff.
Kolbedari, A., Sobhiye, M.H., Ebrahimi, S.N.A. (2018). Develop a theoretical model of governance that affects the performance of large-scale multi-organizational civil partnership projects. Journal of Management Researches in Iran, 22(4), pp. 73-101. [In Persian].

Kraipornsak, P. (2018). Good governance and economic growth: An investigation of Thailand and selected Asian countries. Eurasian Journal of Economics and Finance, 6(1), 93-106.

Krammer, S. M. (2015). Do good institutions enhance the effect of technological spillovers on productivity? Comparative evidence from developed and transition economies. Technological Forecasting and Social Change, 94, 133-154.

Kwon, H. J. and Kim, E. (2014). Poverty reduction and good governance: Examining the rationale of the Millennium Development Goals. Development and Change, 45(2), 353-375.

Levitt, R. E., Henisz, W. J., and Settel, D. (2009, November). Defining and mitigating the governance challenges of infrastructure project development and delivery. In Conference on Leadership and Management of Construction (pp. 2-17).

Lindkvist, L. (2004). Governing project-based firms: Promoting market-like processes within hierarchies. Journal of Management and Governance, 8(1), 3-25.

Lucky, O. O. (2014). Money politics and vote buying in Nigeria: The bane of good governance. Mediterranean Journal of Social Sciences, 5(7), 99-99.

Massey, A. and Johnston-Miller, K. (2016). Governance: Public governance to social innovation?. Policy and Politics, 44(4), 663-675.

McCall, M. K. and Dunn, C. E. (2012). Geo-information tools for participatory spatial planning: Fulfilling the criteria for 'good'governance?. Geoforum, 43(1), 8194.

Méndez-Picazo, M. T., Galindo-Martín, M. Á., and Ribeiro-Soriano, D. (2012). Governance, entrepreneurship and economic growth. Entrepreneurship and Regional Development, 24(910), 865-877.

Miller, R., Lessard, D. R., Michaud, P., and Floricel, S. (2001). Building governability into project structures.

Mira, R. and Hammadache, A. (2017). Good governance and economic growth: A contribution to the institutional debate about state failure in Middle East and North Africa. Asian Journal of Middle Eastern and Islamic Studies, 11(3), 107-120.

Mohammed, F. (2012). Impact of corporate governance on banks performance in Nigeria. Journal of Emerging Trends in Economics and Management Sciences, 3(3), 257-260.

Moreno-Albarracín, A. L., Licerán-Gutierrez, A., OrtegaRodríguez, C., Labella, Á., and Rodríguez, R. M. (2020). Measuring What Is Not Seen-Transparency and Good Governance Nonprofit Indicators to Overcome the Limitations of Accounting Models. Sustainability, 12(18), 7275.

Mungiu-Pippidi, A. (2014). The legacies of 1989: the transformative power of Europe Revisited. Journal of Democracy, 25(1), 20-32.

Munzhedzi, P. H. and Makwembere, S. (2019). Good governance as a solution to local economic 
development challenges in South African municipalities. Journal of Public Administration, 54(41), 659-676.

Mwakaje, A. G., Manyasa, E., Wawire, N., Muchai, M., Ongare, D., Mugoya, C., ... and Nikundiwe, A. (2013). Community-based conservation, income governance, and poverty alleviation in Tanzania: the case of Serengeti ecosystem. The Journal of Environment and Development, 22(1), 51-73.

Nag, N. S. (2018). Government, Governance and Good Governance. Indian Journal of Public Administration, 64(1), 122-130.

Odo, L. U. (2015). Democracy, Good Governance, and Development in Nigeria: The Challenges of Leadership. IOSR-JHSS: IOSR Journal of Humanities and Social Science, 20(6), 01-09.

Ofoegbu, G. N. (2014). New public management and accrual accounting basis for transparency and accountability in the Nigerian public sector. IOSR Journal of Business and Management, 16(7), 104-113.

Omri, A. and Mabrouk, N. B. (2020). Good governance for sustainable development goals: Getting ahead of the pack or falling behind. Environmental Impact Assessment Review, 83, 106388.

Osakede, K., Ijimakinwa, S., Adesanya, T., Ojo, A., Ojikutu, O., and Abubarka, A. (2015). Corruption in the Nigeria public sector: An impediment to good governance and sustainable development. Review of Public Administration and Management, 4(8), 76-87.

Rahaman, K. R. (2018). Social capital and good governance - a nexus for disaster management: lessons learned from Bangladesh. In Living Under the Threat of Earthquakes (pp. 211-228). Springer, Cham.

Ramzy, O., El Bedawy, R., Anwar, M., and Eldahan, O. H. (2019). Sustainable development and good governance. European Journal of Sustainable Development, 8(2), 125-125.

Raszkowski, A. and Bartniczak, B. (2018). Towards sustainable regional development: economy, society, environment, good governance based on the example of Polish regions. Transformations in Business and Economics, 17(2 (44)).

Raza, S. A., Shah, N., and Arif, I. (2019). Relationship between FDI and economic growth in the presence of good governance system: Evidence from OECD Countries. Global Business Review, 0972150919833484.

Razak, M. R. R. and Ali, A. (2020). child social welfare institution participation in the implementation of good governance. Jurnal Ilmiah Ilmu Administrasi Publik, 9(2), 345-354.

Reside, R. E. and Mendoza, A. M. (2010). Determinants of outcomes of public-private partnerships (PPP) in infrastructure in Asia (No. 2010, 03). UPSE Discussion Paper.

Rezaei, J. (2016). Best-worst multi-criteria decisionmaking method: Some properties and a linear model. Omega, 64, 126-130.

Ruben, R. and Heras, J. (2012). Social capital, governance and performance of Ethiopian coffee cooperatives. Annals of Public and Cooperative Economics, 83(4), 463-484.

Sandelowski, M. and Barroso, J. (2006). Handbook for synthesizing qualitative research. springer publishing company.

Shikha, V. Y. A. S. and Aktan, C. C. (2017). Progression from ideal state to good governance: An introductory overview. International Journal of Business and Management Studies, 9(1), 29-49.

Stojanović, I., Ateljević, J., and Stević, R. S. (2016). Good governance as a tool of sustainable development. European Journal of Sustainable Development, 5(4), 558-558.

Turner, J. R. (2018). The management of the project-based organization: A personal reflection, 231-240.

Turner, R., Huemann, M., and Keegan, A. (2008). Human resource management in the project-oriented organization: Employee well-being and ethical treatment. International Journal of Project Management, 26(5), 577-585.

Valentinov, V., Verschraegen, G., and Van Assche, K. (2019). The limits of transparency: A systems theory view. Systems Research and Behavioral Science, 36(3), 289-300.

Waheduzzaman. (2010). Value of people's participation for good governance in developing countries. Transforming Government: People, Process and Policy, 4(4), 386-402.

Weiss, T. G. (2000). Governance, good governance and global governance: conceptual and actual challenges. Third world quarterly, 21(5), 795-814.

Whitley, R. (2006). Project-based firms: new organizational form or variations on a theme? Industrial and corporate change, 15(1), 77-99.

Winston, K. (2012). Educating for moral competence (for Philip Selznick). Issues in Legal Scholarship, 10(1), 18-32.

Yousaf, M., Ihsan, F., and Ellahi, A. (2016). Exploring the impact of good governance on citizens' trust in Pakistan. Government Information Quarterly, 33(1), 200-209.

Zaman, K. (2015). Quality guidelines for good governance in higher education across the globe. Pacific Science Review B: Humanities and Social Sciences, 1(1), 1-7.

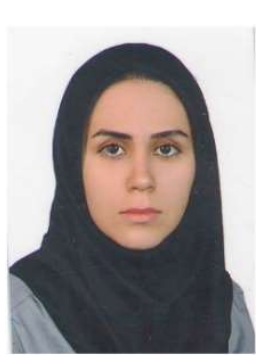

(COM).

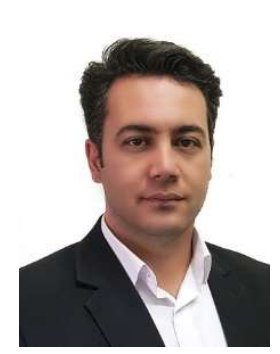

Samira Aeini is an MSc student in Project and Construction Management from Noore Touba University, Tehran, Iran. She is a member of the Otto architectural and urbanism institute. Her research interests include Construction Management, Building Information Modelling (BIM), and Maintainability concepts

Dr. Mehdi Delavari got a Ph.D. in project management and construction from Tarbiat Modares University, Tehran, Iran. His research interests include Project Portfolio Management, PMIS, Project Management System and Corporate Governance. 
86 Aeini, S., Delavari, M., and Goldust, Y.

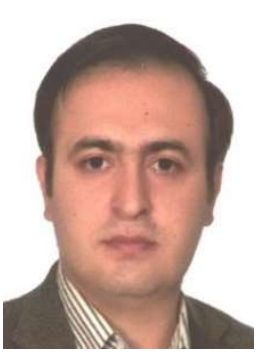

Dr. Yaser Goldust received his Ph.D.

in project management and construction from Tarbiat Modares University, Tehran, Iran. $\mathrm{He}$ is currently Assistant professor, Department of Architecture, Faculty of Art and Architecture, University of Mazandaran, Babolsar. His research interests include Project Portfolio Management, PMIS, Project Management System, and Corporate Governance. 